УДК 94(571.54)+94(517.3)

ПЛЕХАНОВА Анна Максимовна - доктор исторических наук, доцент; ведущий научный сотрудник отдела истории, этнологии и социологии Института монголоведения, буддологии и тибетологии СО РАН (670047, Россия, Республика Бурятия, г. Улан-Удэ, ул. Сахьяновой, 6; plehanova.ат@ mail.ru)

ШИРАПОВ Алдар Амаголонович - аспирант Института монголоведения, буддологии и тибетологии СО РАН (670047, Россия, Республика Бурятия, г. Улан-Удэ, ул. Сахьяновой, 6; agтагеп@таil.ru)

\title{
ВЕРХНЕУДИНСКОЕ ОТДЕЛЕНИЕ РУССКО- КИТАЙСКОГО БАНКА: НАПРАВЛЕНИЯ, СПЕЦИФИКА И РЕЗУЛЬТАТЫ ДЕЯТЕЛЬНОСТИ В УСЛОВИЯХ ТРАНСГРАНИЧЬЯ
}

Аннотация. В статье исследуется деятельность Верхнеудинского отделения Русско-Китайского банка, являвшегося в начале XX в. экономическим инструментом укрепления российского влияния в трансграничье России, Китая и Монголии. Авторы анализируют работу отделения в области предоставления типичных банковских предложений населению Западного Забайкалья (кредитование, осуществление денежных переводов, прием вкладов) и нетипичных для финансово-кредитного учреждения услуг, таких как страхование имущества, поддержка предпринимательской активности клиентов банка за рубежом. Выявлена специфика деятельности Верхнеудинского отделения, проявившаяся во взаимовыгодном сотрудничестве с учреждением банка в Урге в интересах продвижения российского торгово-финансового капитала в регионы Внутренней Азии.

Ключевые слова: Русско-Китайский банк, трансграничье, Верхнеудинск, Монголия, кредит, ссуда, перевод, страхование

$\mathrm{B}$ конце XIX в. Российская империя проводила активную экспансию на Дальнем Востоке с целью укрепления своих слаборазвитых восточных территорий, особенно стратегически важных трансграничных регионов Внутренней Азии. Кроме того, для усиления позиций российского торговофинансового капитала требовалось получить выход на новые рынки сбыта в странах Азиатско-Тихоокеанского региона. Для достижения поставленных целей использовались как военные и дипломатические, так и экономические методы. Одним из наиболее важных и эффективных экономических инструментов укрепления влияния России в регионе стал организованный под патронажем Министерства финансов Российской империи Русско-Китайский банк (1896-1910 гг.).

Изучение содержания и результатов деятельности Русско-Китайского банка нашло отражение в трудах Б.А. Романова, И.В. Лукоянова, К. Яго, С.А. Саломатиной и Е.Д. Тужилиной, Л.В. Кураса и Л.В. Кальминой и др. [Романов 1928; Лукьянов 2008; Яго 2012; Саломатина, Тужилина 2016; Курас, Кальмина 2018]. Следует отметить, что исследователи проблемы сосредоточили внимание в основном на анализе международной активности РусскоКитайского банка. Деятельность филиалов и отделений банка, особенно расположенных в отдаленных районах страны, пока что не получила широкого освещения и представляет большой интерес для исследователей.

Задачей данной статьи является изучение и анализ работы Верхнеудинского отделения Русско-Китайского банка в период после окончания Русскояпонской войны (1904-1905 гг.) и до его реорганизации в Русско-Азиатский банк путем слияния с Северным банком 27 июня 1910 г. Особый акцент будет сделан на определении места отделения в организационной системе банка (по 
отношению к другим отделениям) и выявлении направлений, специфики и результатов его деятельности. Выбор данного объекта исследования обусловлен значительным влиянием деятельности Верхнеудинского отделения банка на процесс укрепления торгово-промышленных связей Западного Забайкалья с европейской частью Российской империи. Кроме того, благодаря своему географическому положению отделение играло заметную роль в деле продвижения российского влияния в северные провинции Китая.

Русско-Китайский банк был создан 10 декабря 1895 г. по инициативе министра финансов Российской империи С.Ю. Витте (1892-1903 гг.), который 14 июля 1895 г. подал императору Николаю II «Всеподданнейший доклад министра финансов С.Ю. Витте об учреждении Русско-Китайского банка в Китае и командировании туда в качестве официального агента Министерства финансов и служащего банка делопроизводителя Общей канцелярии министра финансов Д.Д. Покотилова». Правление банка было решено расположить в СанктПетербурге.

Перед новым банком руководство империи поставило ряд задач. Во-первых, согласно Уставу 1895 г. Русско-Китайский банк имел «своим исключительным назначением поддержку торговых сношений с государствами Восточной Азии» ${ }^{1}$. Вторая задача была продиктована результатами японо-китайской войны (1894-1895 гг.), после поражения в которой на Китайскую империю была наложена контрибуция в размере 200 млн лянов [Гримм 1927: 95]. Для организации процедуры выплаты этой суммы французские и российские банки создали в 1895 г. синдикат для размещения на рынке бумаг китайского займа. Контроль и управление этими займами были возложены на Русско-Китайский банк. В-третьих, согласно положениям контракта на постройку и эксплуатацию Китайско-Восточной железной дороги, заключенного между Российской и Китайской империями 27 августа 1896 г. в Берлине, Русско-Китайскому банку поручалась постройка и эксплуатация КВЖД². Кроме того, Русско-Азиатский банк должен был оказывать финансовую поддержку торговле между Россией и Китаем. До учреждения банка расчеты между российскими и китайскими предпринимателями велись через иностранные банки, главным образом через банк «Гонконгско-Шанхайская банковская корпорация», что ставило русских купцов в заведомо проигрышное положение по сравнению с их иностранными конкурентами [Яго 2012: 295].

К началу Русско-японской войны (1904-1905 гг.) банк показывал достаточно устойчивую динамику развития и стал основным каналом проникновения российского капитала в регион. Финансовая организация имела разветвленную сеть отделений. Так, по состоянию на 1902 г., отделения Русско-Китайского банка, кроме столичных - в Санкт-Петербурге и Москве, - находились в Благовещенске, Верхнеудинске, Витиме, Владивостоке, Иркутске, Кашгаре, Коканде, Красноярске, Кяхте, Николаеве, Самарканде, Сретенске, Хабаровске и Чите. На территории Китая отделения банка функционировали в г. Далянь, Куанченцзы, Ньючванг (Нью-Чжуан), Пекин, Тяньцзинь, Хайлар, Ханкоу, Харбин, Цзилинь, Чифу, Шанхай; в Японии - в г. Кобе, Йокогама, Нагасаки. Представительство банка в Западной Европе располагалось в Париже.

Поражение в Русско-японской войне радикальным образом отразилось на положении Русско-Китайского банка, фактически прекратив его международную финансовую активность, заставив перенаправить свою деятельность на

\footnotetext{
1 Устав Русско-Китайского банка. Утв. 10 дек. 1895 г. СПб. 1895. С. 10.

2 Сборник договоров России с другими государствами. 1856-1917 (под ред. Е.А. Адамова). М.: Госполитиздат. 1952. С. 297.
} 
внутренний рынок Российской империи [Лукоянов 2008: 187-188]. В этих условиях возросло значение отделений банка как проводников финансовой экспансии Русско-Китайского банка в слаборазвитые восточные регионы империи.

В конце XIX в. банковское дело на территории Западного Забайкалья было развито сравнительно слабо. Первый банк в регионе был открыт в 1844 г. по инициативе и на средства известного купца и мецената Я.А. Немчинова в г. Троицкосавске (Кяхта). Данный банк был предназначен для «вспомоществования малокапитальному купечеству» в торговых делах ${ }^{1}$. В 1882 г. с разрешения министра финансов Российской империи при городской думе был учрежден Верхнеудинский городской общественный банк. Капитал банка, составлявший 10 тыс. руб., формировался из общественных средств, пожертвований, взносов частных лиц. Сохранность вносимых вкладов гарантировалась городским имуществом. За все время существования банка - с 22 августа 1882 г. по 1 сентября 1886 г. - его общий оборот достиг 1824599 руб. 78 коп. [Кальмина 2017: 83].

Деятельность данных финансово-кредитных учреждений вследствие слаборазвитой связи с европейской частью Российской империи носила локальный характер. Они просуществовали недолгое время. Интересы предпринимателей региона диктовали необходимость открытия банка, обладающего достаточными ресурсами для кредитования в крупных размерах, имеющего развитую инфраструктуру, технически оснащенного, располагающего профессиональным кадровым составом и широкой географией межбанковских связей. Именно таким учреждением стал Русско-Китайский банк.

Отделение Русско-Китайского банка в г. Верхнеудинске было открыто в 1897 г. В организационной структуре банка отделение вошло в группу, в которой, кроме Верхнеудинского, состояли Красноярское, Кяхтинское, Иркутское и Ургинское отделения ${ }^{2}$. Руководящим в группе было Иркутское отделение, которое разрабатывало и рассылало шифровальные ключи для операций с чеками и аккредитивами 3 . Здание Верхнеудинского отделения банка располагалось на Большой улице (ул. Ленина, 29) в доме городского головы (18991901 гг.) купца Павла Тивуртиевича Трунева (1862-1931 гг.), который был назначен директором Верхнеудинского отделения банка.

На 1 августа 1910 г. штат сотрудников банка насчитывал 18 чел.: директор, 11 банковских сотрудников, юрисконсульт, «артельщик» (заведующий хозяйством), швейцар, сторож и двое «мальчиков» (помощники-курьеры) ${ }^{4}$. Общий размер жалованья сотрудников банка, ассигнованного по сметам на 1 августа 1910 г., составлял 17300 руб. ${ }^{5}$ Налогов и податей за служащих банк выплатил в городское казначейство на сумму 1157 руб. 59 коп 6.

Верхнеудинское отделение Русско-Китайского банка выполняло следующие операции.

1. Аккумуляция временно свободных денежных средств. На 1 января 1909 г. на счетах клиентов банка насчитывалось 359405 руб., из которых срочных вкладовна сумму 344550 руб., вкладов до востребования - 14855 руб. ${ }^{7}$

2. Кредитование клиентов. Так, на 1 ноября 1910 г. ссуд под заем процентных бумаг было выдано на сумму в 35585 руб. при оценочной стоимости данных

1 Становление банковского сектора в Бурятии. - Агентство ВЭП (для банков и банковских специалистов). Доступ: http://www.vep.ru/bbl/history/cbr-118.html (проверено 14.03.2019).

2 Государственный архив Республики Бурятия (ГАРБ). Ф. 224. Оп. 1. Д. 36. Л. 38.

3 Там же. Д. 13. Л. 49.

4 Там же. Д. 64. Л. 27-28.

5 Там же. Л. 29.

6 Там же. Л. 194.

7 Там же. Д. 43А. Л. 122, 124. 
бумаг в 49472 руб. ${ }^{1}$ Кроме того, с 6 октября 1907 г., согласно циркуляру № 103 Санкт-Петербургского правления банка, была открыта выдача кредитов по товарно-ссудным операциям, что было особенно важно для клиентов банка в Западном Забайкалье: ссуду с определенными условиями можно было получить под залог продуктовых товаров ${ }^{2}$ К К декабрю 1908 г. было выдано 112 подобных ссуд. К примеру, М.Г. Ицкович за 700 пудов топленого говяжьего сала (стоимостью 4200 руб.) получил от отделения 2500 руб. ссуды ${ }^{3}$.

3. Денежные переводы, обналичивание чеков. Верхнеудинское отделение Русско-Китайского банка обеспечивало надежный перевод и выдачу денежных средств своим клиентам. Так, на 1 января 1909 г. из отделения по почте было принято 63112 руб., отправлено - 30955 руб. Телеграфными переводами было отправлено 94543 руб., принято - 239872 руб. ${ }^{4}$ Данная услуга была чрезвычайно удобна для клиентов банка - российских подданных, работающих за рубежом, в Монголии и Китае.

4. Страхование имущества. Данная услуга являлась достаточно нетипичной для банковской деятельности, но, согласно пп. 12 п. 14 своего Устава, РусскоКитайский банк имел право производить страхование товаров от «огня и других несчастных случаев» 5 .

Русско-Китайский банк 24 июня 1908 г. заключил соглашение с третьим по значимости игроком на страховом рынке Российской империи - страховым товариществом «Саламандра» (1846-1922 гг.). По данному соглашению РусскоКитайский банк брал на себя страховую агентуру «Саламандры» ${ }^{6}$. Отделения банка в Сибири, Маньчжурии и Туркестане начали осуществлять страховые операции с 1 сентября 1908 г. $^{7}$ В основном страховались продовольственные товары и свечи, причем достаточно большие партии. Так, в июле 1910 г. были застрахованы 4 вагона муки-крупчатки и 1 вагон сливочного масла. Прибыль банка от страховых операций на 1 июля 1910 г. составила 748 руб. ${ }^{8}$ Страхование товара стало необходимым условием в случае получения клиентом банка ссуды под залог товаров. К примеру, выданная ссуда в размере 10320 руб. под залог партии мороженого мяса (4 300 пудов) стоимостью в 15480 руб. была застрахована на 11350 руб. 9

Наряду с этими направлениями деятельности Верхнеудинское отделение Русско-Китайского банка оказывало содействие своим клиентам в осуществлении торговых операций. Так, отделение отправило письмо коллегам в банк в Куанченцзы (Китай) с просьбой об оказании поддержки купцу Н.Л. Капельману в оплате фрахта и выкупе вагонов с лесными материалами. Просьба была удовлетворена 10 .

Особый интерес представляет взаимодействие Верхнеудинского отделения с Ургинским учреждением Русско-Китайского банка в Монголии. Точная дата основания отделения банка в Урге не установлена. Согласно данным отчета по операциям Русско-Китайского банка, доля монгольского отделения в валовой прибыли отделений банка впервые указывается по итогам 1903 г. - 0,39\%

\footnotetext{
1 Там же. Д. 64. Л. 103.

2 Там же. Д. 43 А. Л. 60.

3 Там же. Д. 64. Л. 139.

4 Там же. Д. 43А. Л.134.

5 Устав Русско-Китайского Банка. Утв. 10 дек. 1895 г. СПб. 1895. С. 14.

6 ГАРБ. Ф. 224. ОП. 1. Д. 146. Л. 67.

7 Там же. Л. 70.

8 Там же. Оп. 1. Д. 64. Л. 31.

9 Там же. Л. 139.

10 Там же. Оп. 1. Д. 13. Л. 28.
} 
[Яго 2012: 306]. Директором отделения значился М. Осокин. В своей деятельности отделение в Урге было тесно связано с Верхнеудинским, прежде всего в плане операций с денежными средствами клиентов банка, таких как выписка чеков, телеграфные переводы. Всего на 22 декабря 1908 г. Ургинское отделение выписало 1544 чека ${ }^{1}$, многие - на весьма крупные суммы (так, Д.Д. Дашееву был выписан чек на 10000 руб. ${ }^{2}$ ). При работе с векселями клиентов монгольское отделение банка ориентировалось на информацию, предоставляемую Верхнеудинским отделением. Ургинское отделение банка регулярно запрашивало и получало списки лиц - владельцев векселей, «протестованные» (проверенные) верхнеудинскими нотариусами ${ }^{3}$. В свою очередь, из монгольского учреждения в Верхнеудинское отправлялись списки лиц, проверенные консульством Российской империи в Урге 4 .

Не менее заслуживающим внимания фактом в работе Верхнеудинского и Ургинского отделений Русско-Китайского банка является их совместная деятельность, связанная с продвижением на монгольский рынок российских товаров. Согласно пп. 2 п. 14 Устава банк имел право производить «покупку и продажу за свой счет по поручению частных лиц и торговых домов товаров и всякого рода процентных бумаг, акций, паев и облигаций» 5 . Исходя из сообщения из Урги от 31 июля 1908 г., Верхнеудинское отделение заказало провести маркетинговое исследование рынка сбыта спичек в Монголии ${ }^{6}$. Согласно полученной информации, стоимость одного ящика спичек в Урге составляла 7 руб. Местное отделение банка с готовностью бралось за распространение данного товара на монгольском рынке 7 . Наряду с продвижением в Монголию товаров массового потребления отделения банка в Верхнеудинске и Урге проводили совместные исследования возможности сбыта в Монголии и более дорогой продукции, рассчитанной на состоятельных клиентов. К примеру, 11 июля 1908 г. из Урги в Верхнеудинск обратно была отправлена посылка с образцами парчи производства фабрики И.А. Жевержеева (г. Санкт-Петербург), присланная ранее для демонстрации ${ }^{8}$.

Таким образом, Верхнеудинское отделение занималось обычными для учреждения коммерческого банка операциями - приемом вкладов у населения, выдачей ссуд, осуществлением денежных переводов и т.д. В то же время отделение решало и достаточно нетипичные для своей деятельности задачи, такие как страхование движимого имущества и оказание содействия своим клиентам в торговых операциях за рубежом.

Географическое расположение Верхнеудинского отделения предопределило специфику его деятельности в условиях трансграничья, проявившуюся в тесном взаимодействии с монгольским отделением Русско-Китайского банка. Стоит отметить, что сотрудничество двух учреждений было взаимовыгодным. Предоставляемые Верхнеудинском информационные сведения и материалы имели важное значение для деятельности Ургинского отделения. В свою очередь, сотрудники банка в Урге осуществляли в интересах Верхнеудинского отделения сбор и обработку информации о возможности сбыта российских товаров на монгольском рынке.

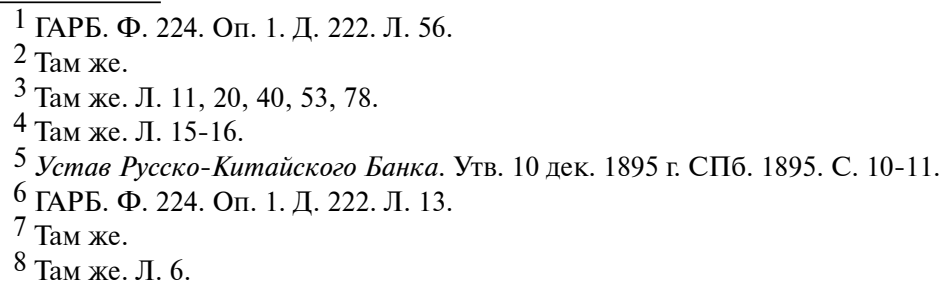


Верхнеудинское отделение Русско-Китайского банка оказало заметное влияние на экономическую жизнь Западного Забайкалья. Благодаря работе банка местные предприниматели, используя его материальные и информационные ресурсы, обрели возможность расширить и улучшить сферу своей деятельности как на территории Российской империи, так и в странах Внутренней Азии. Привлечение банком свободных денежных средств населения обеспечило вливание в финансовую систему региона капиталов, ранее активно не участвовавших в обороте. Жители Западного Забайкалья получили доступ к дополнительным возможностям в области кредитования для открытия собственного дела, улучшения материальных условий жизни. Благодаря работе Верхнеудинского отделения дело продвижения российского влияния на территорию Монголии обрело дополнительную поддержку.

Статья подготовлена в рамках государственного задания (проект ХII.191.1.1. «Трансграничье России, Монголии и Китая: история, культура, современное общество», номер госрегистрации № АAАA-А17-117021310269-9).

\section{Список литературы}

Гримм Э.Д. 1927. Сборник договоров и других документов по истории международных отношений на Дальнем Востоке (1842-1925). М.: Институт востоковедения. $218 \mathrm{c}$.

Кальмина Л.В. 2017. Верхнеудинский общественный банк в контексте финансовой политики самодержавия. - Известия Иркутского государственного университета. Сер. Политология. Религиоведение. Т. 21. С. 79-85.

Курас Л.В., Кальмина Л.В. 2018. Русско-Китайский банк в системе международных отношений в Восточной Азии и кяхтинское купечество (конец XIX - начало ХХ в.). - Власть. Т. 26. № 5. С. 149-153.

Лукоянов И.В. 2008. «Не отстать от держав...» Россия на Дальнем Востоке в коние ХІХ-начале ХХ вв. СПб: Нестор-История. 668 с.

Романов Б.А. 1928. Россия в Маньчжмрии (1892-1906). Очерки по истории внешней политики самодержавия в эпоху империализма (под ред. Ю.В. Визе, Р.Л. Самойловича). Л.: Изд-во Восточного института. 605 с.

Саломатина С.А., Тужилина Е.Д. 2016. Банк «для своих»: Московское отделение Русско-Китайского банка в 1897-1899 гг. - Экономическое развитие России в ХІХ-начале ХХ века. № 4(35). С. 47-61.

Яго К. 2012. Русско-Китайский банк в 1896-1910 гг.: международный финансовый посредник в России и Азии. - Экономическая история: ежегодник 2011/2112. М.: РОССПЭН. С. 293-314. 